Bulgarian Academy of Sciences. Space Research and Technology Institute.

Aerospace Research in Bulgaria. 33, 2021, Sofia

DOI: https://doi.org/10.3897/arb.v33.e06

\title{
SEASONAL CHANGES OF SAHARA DESERT DUST TRANSPORT OVER BALKANS
}

\author{
Maria Dimitrova \\ Space Research and Technology Institute - Bulgarian Academy of Sciences \\ e-mail:maria@space.bas.bg
}

Keywords: Remote Sensing, Air Pollution, Dust Pollution, Ecology

\begin{abstract}
This article presents an investigation of seasonal behaviour of the Sahara desert dust transport over the Balkans. The data used are satellite measurements of monthly averaged Absorption Aerosol Index (AAI) value. The research period is from June 1995 to the end of 2019. The data used is from four space instruments onboard five satellites. The area of interest is a rectangle with corners $23 \mathrm{E} 43 \mathrm{~N}$ and $245 \mathrm{E} 35 \mathrm{~N}$. The data from different sources are compared and discussed.
\end{abstract}

\section{Introduction}

Mineral dust is the second largest source of natural aerosols. North African deserts emit most of the dust particles released into the atmosphere worldwide.

The smallest dust particles strongly affect human health (mainly the respiratory system).

The physics, chemistry and biology of marine atmosphere and biogeochemical cycles in seawater are strongly influenced by the atmospheric transport and deposition of mineral aerosol particles, which are massively exported from the desert areas. Sahara and the peripheral regions are the main source of soil-derived aerosols over the Atlantic and Mediterranean.

Desert dust transports minerals, bacteria and other small pollutants. Cristal aerosols influence the atmospheric radiative balance through scattering and absorption, and by acting as cloud condensation nuclei when sulphation and nitration occur.

It is now well known that satellite observations of the sunlight reflected by the Earth-atmosphere system enable relatively accurate retrieval of the vertically integrated dust aerosol content over the ocean in terms of optical thickness [1,2]. Remote sensing by operational meteorological onboard sensors is suitable for 
monitoring large desert dust plumes, which exhibit high temporal and spatial variability.

These dust plumes are spread over thousands of kilometers, and can persist for many days. They have extremely deleterious effects on the air quality near the African continent but are also important on a global scale.

Some authors during the last decades investigate dust transport over the Mediterranean [1-6], more often in direction towards Italy and Spain [7] and even more scientists paid attention to dust transport over the Atlantic [8-11]. Results indicate that during "African dust-events", the numbers of cultivatable airborne microorganisms can be 2 to 3 times more than these found during "clear atmospheric conditions" $[12,13]$. There are no exhaustive investigations done on the influence of the Sahara dust over the Balkans.

In this paper, we use monthly averaged satellite data of AAI (Absorption Aerosol Index), which has a close to linear dependence with optical depth from five satellites for the period 1995 until the end of 2019 to investigate seasonal behaviour over the Balkans in nine areas in direction North - South.

\section{Area of interest, satellite data and investigation methods}

In this work we research seasonal behaviour (and its variations) of dust atmospheric pollution from Africa in North - South direction over the Balkans. invested area is rectangle with corners respectively $23 \mathrm{E} 43 \mathrm{~N}$ and $245 \mathrm{E} 35 \mathrm{~N}$.

We choose nine areas (cells of $1 \times 1$ degrees). Points indicate the center of each area (Fig. 1).
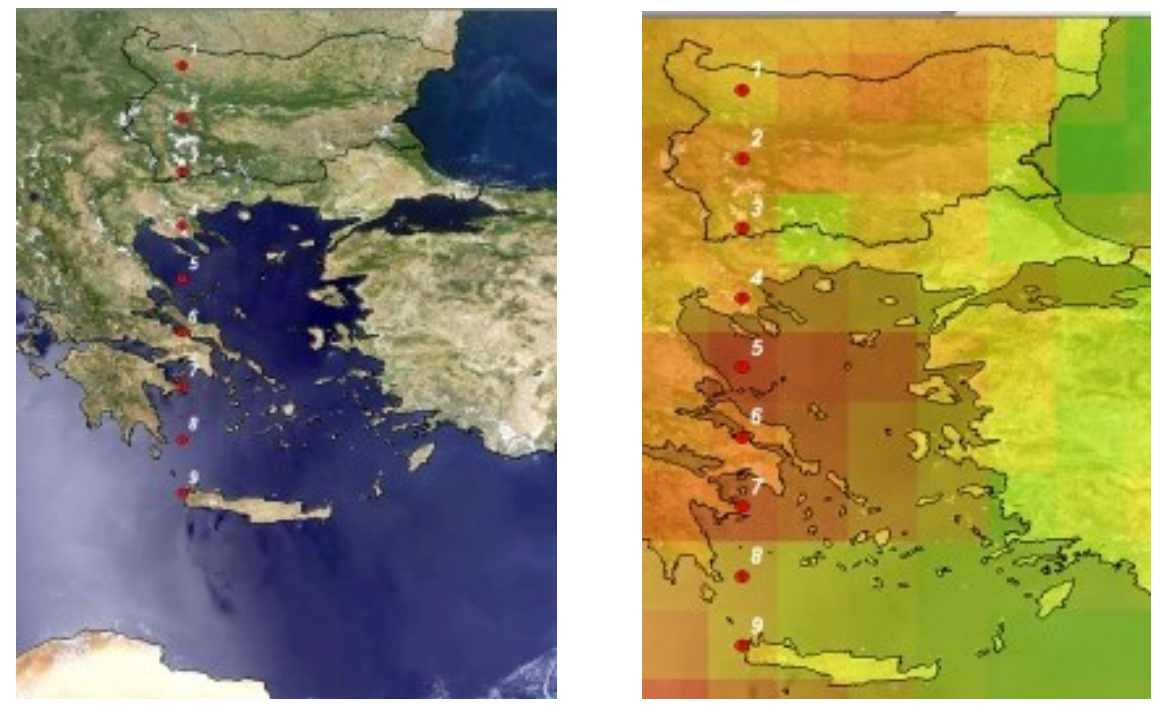

Fig. 1. Area of interest. On the left-optical image from MODIS with points. On the right - combined image AAI from GOME-2 over the same optical picture and points. 
We use satellite data from four space instruments onboard five satellites with similar space and temporal resolution as follows:

- GOME onboard ERS-2 - from 6.1995 till $6.2003(40 \times 40 \mathrm{~km})$

- $\quad$ SCIAMACHY onboard ENVISAT - from 9.2002 till $4.2012(30 \times 60 \mathrm{~km})$

- OMI onboard AURA - from 9.2004 till now $(40 \times 40 \mathrm{~km})$

- GOME-2 onboard MetOp A - from 1.2007 till now $(40 \times 40 \mathrm{~km})$

- GOME-2 onboard MetOp B - from 12.2012 till now $(40 \times 80 \mathrm{~km})$ shown.

On fig. 2 it the working duration of each one of these instruments is

In the figure, we show GOME-2 instrument onboard MetOp C satellite. We do not include data from them later on because data are available only for one year.

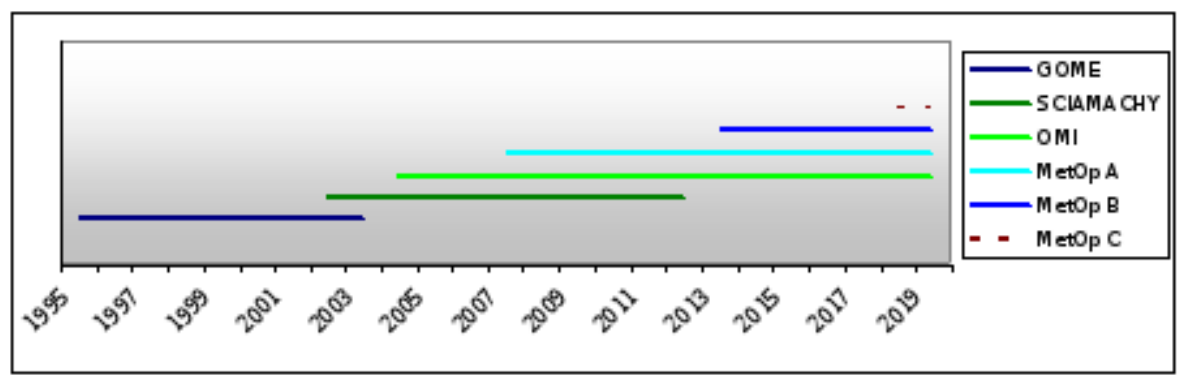

Fig. 2. The working duration of chosen space instruments

We choose to use monthly averaged data for AAI in "*.nc" format (Longitude: 360 bins centered on $179.5 \mathrm{~W}$ to $179.5 \mathrm{E}$ (1 degree steps), Latitude: 180 bins centered on $89.5 \mathrm{~S}$ to $89.5 \mathrm{~N}$ (1 degree steps) from ESA - TEMIS (Tropospheric Emission Monitoring Internet Service) [14].

There is free data for almost every day during the work time of each one of the chosen instruments.

The Absorbing Aerosol Index (AAI) indicates the presence of elevated absorbing aerosols in the Earth's atmosphere. The aerosol types that are mostly seen in the AAI are desert dust and biomass-burning aerosols. The AAI provided here are derived from the reflectance measured by GOME-1, SCIAMACHY and GOME-2 at 340 and $380 \mathrm{~nm}$, and from the reflectance measured by OMI at 354 and $388 \mathrm{~nm}$. 


\section{Results}

For every instrument and each year it's working we built graphics of dependence AAI - month of year. Then, we obtained an average value of AAI for each area and month.

We do not show results for the $5^{\text {th }}$ and the $8^{\text {th }}$ areas, because these areas are fully over sea regions. Our interest is focused on the spatial dust transport distribution over land areas. Results we show in Figures 3-7.

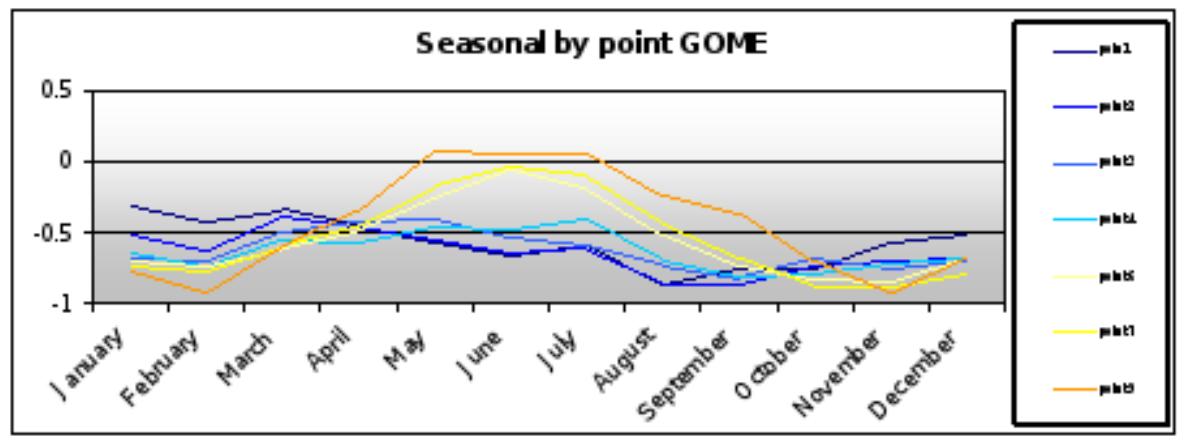

Fig. 3. Seasonal behaviour of averaged AAI by points from GOME instrument

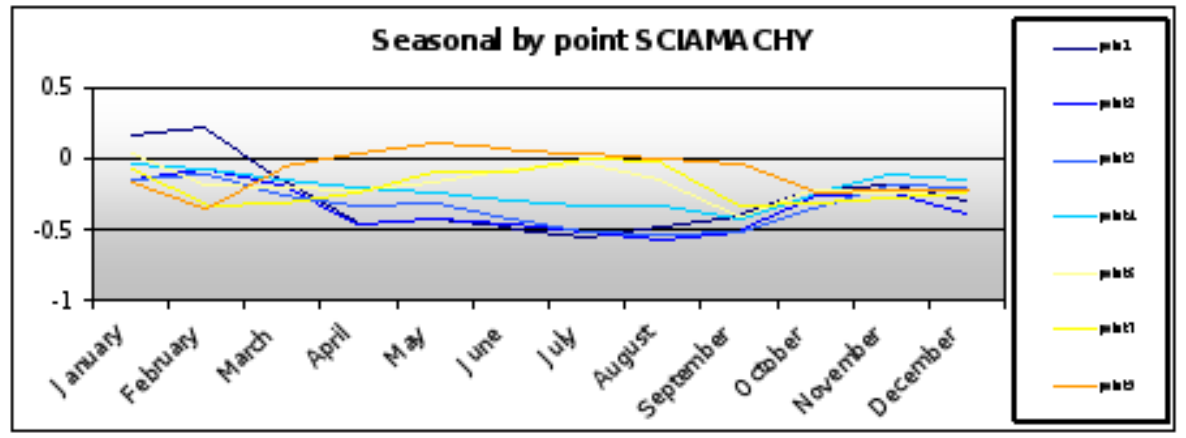

Fig. 4. Seasonal behaviour of averaged AAI by points from SCIAMACHY instrument 


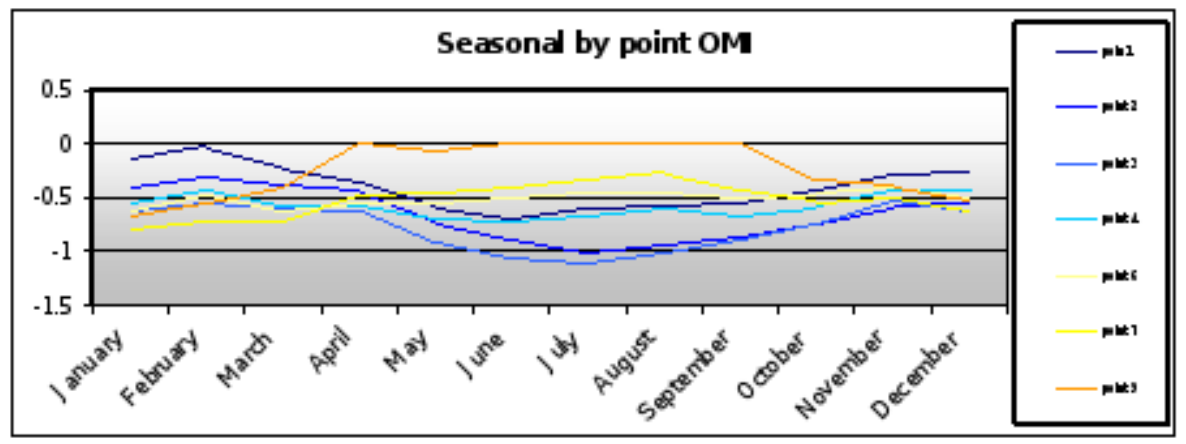

Fig. 5. Seasonal behaviour of averaged AAI by points from OMI instrument

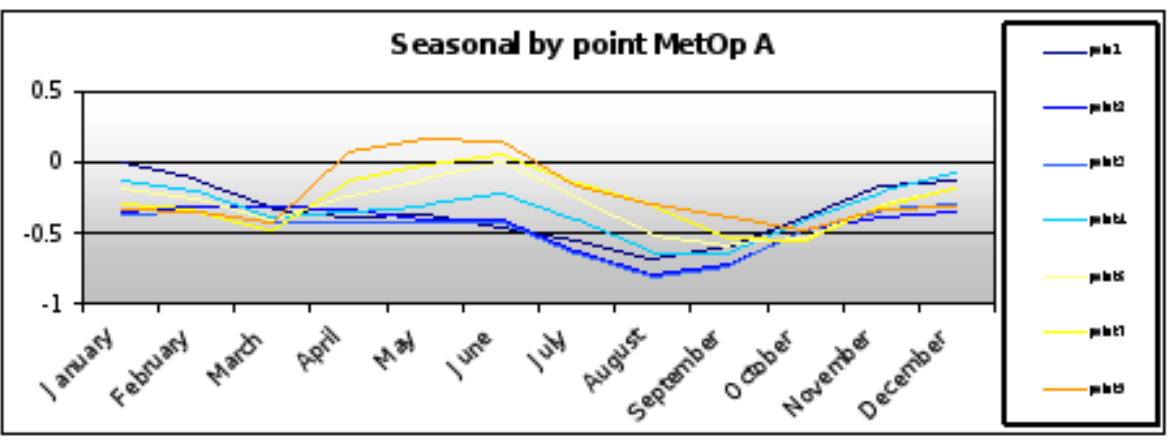

Fig. 6. Seasonal behaviour of averaged AAI by points from GOME-2 instrument onboard MetOp A satellite

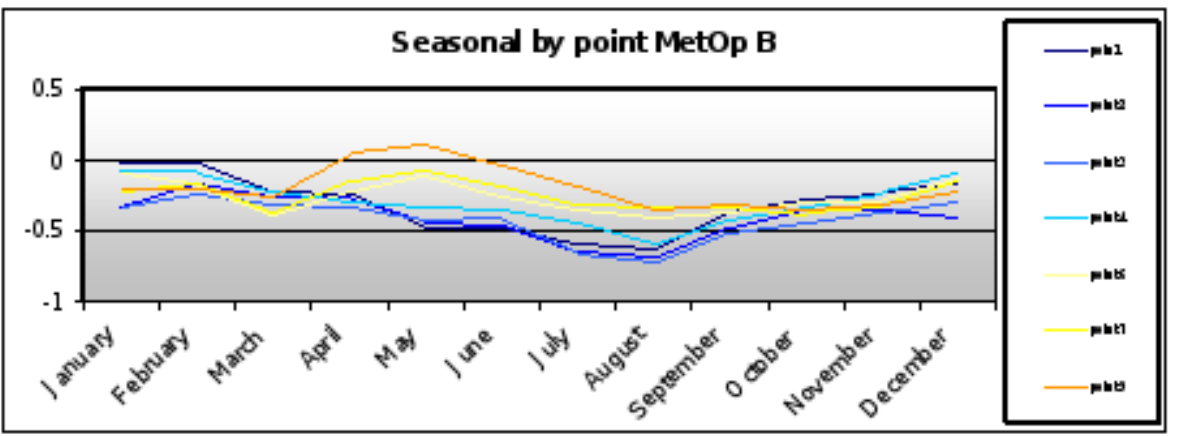

Fig. 7. Seasonal behaviour of averaged AAI by points from GOME-2 instrument onboard MetOp B satellite

As it is seen from the above figures, seasonal AAI behaviour is different for different areas. Areas from $1^{\text {st }}$ to $4^{\text {th }}$ show an increase of AAI for winter 
months, while areas $6^{\text {th }}, 7^{\text {th }}$ and $9^{\text {th }}$ show significant increases in AAI during summer. Moreover, - AAI increase with an increase in the point number. As our previous investigations show [15], sand storms from Africa during the last 15 years are mainly in winter months (from February till June). Results from the older instruments (GOME and SCIAMACHY) show a longer period with increase - till October.

As the area number increases with the decrease of Latitude, it shows increasing of desert dust with Latitude decreases. For illustrating above conclusion and comparison of data from different instruments, on fig. 8 we show averaged AAI value for each area.

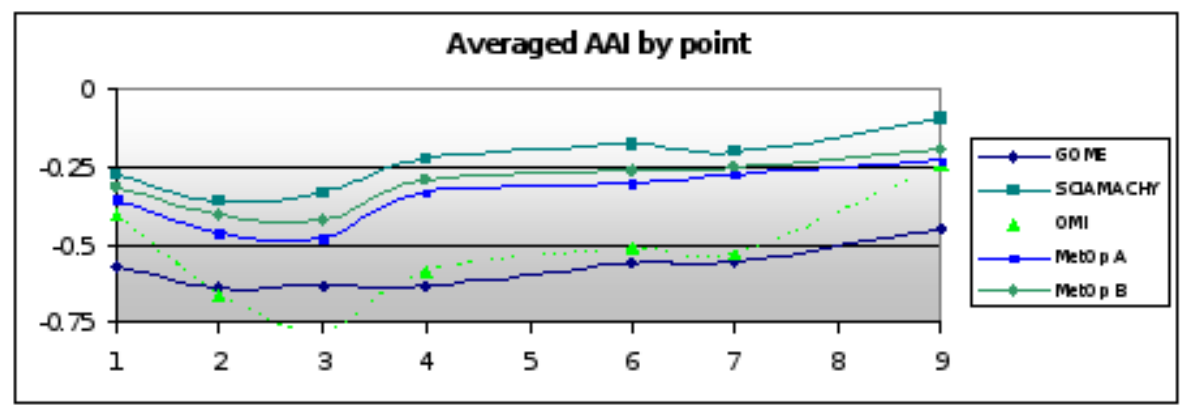

Fig. 8. averaged AAI value for each instrument and different areas

As it is seen from the last above graphic - averaged AAI for last area has the highest value. AAI differences in areas are similar for GOME-2 and SCIAMACHY instruments. Data from GOME show similar behaviour but lower values.

It seems that the combination of data from OMI with data from other mentioned instruments is not corrected. The reason for it may be longer and nonstable work of the satellite and the different spectral diapason of AAI measurement of this instrument.

\section{Conclusions}

As a result of this research, we can conclude that satellite data for AAI show the expected increase in south direction. It means that the dust transport affects the southern Balkan areas (here Crete) stronger then the northern Bulgarian regions. The seasonal behaviour shows changes during the last 15 years. While earlier sand transport continues from February until October, during the last decade it shows increase only from March to July with outstanding maximum around May. 


\section{References}

1. Moulin, C. and F. Guillard, Long-term daily monitoring of Saharan dust load over the ocean using Meteosat ISCCP-B2 data 1. Methodology and preliminary results for 1983-1994 in the Mediterranean, Journal of Geophysical Research, 1997, 102, D14, 16947-958.

2. Moulin, C., C. E. Lambert, U. Dayan, T. M V. Masson, M. Ramonet, P. Bousquet, M. Legrand, Y. J. Balkanski, W. Guelle, B. Marticorena, G. Bergametti, and F. Dula, Satellite climatology of African dust transport in the Mediterranean atmosphere, Journal of Geophysical Research, 1998, 103, Dll, 13137-144.

3. Kubilay, N., Sl. Nickovic, C. Moulin, and F. Dulac, An illustration of the transport and deposition of mineral dust onto the eastern Mediterranean, Atmospheric Environment, 2000, 34, 1293-1303.

4. Querol, X., J. Peya, M. Pandolfi, A. Alastuey, M. Cusack, N. Per rez, T. Moreno, M. Viana, N. Mihalopoulos, G. Kallos, and S. Kleanthous, African dust contributions to mean ambient PM10 mass-levels across the Mediterranean Basin, Atmospheric Environment, 2009, 43, 4266-77.

5. Pey, J., X. Querol, A. Alastuey, F. Forastiere, and M. Stafoggia, African dust outbreaks over the Mediterranean Basin during 2001-2011: PM10 concentrations, phenomenology and trends, and its relation with synoptic and mesoscale meteorology, Atmos. Chem. Phys., 2013, 13, 1395-1410.

6. Salvador, P., S. Alonso-Pérez, J. Pey, B. Artíñano, J. J. de Bustos, A. Alastuey, and X. Querol, African dust outbreaks over the western Mediterranean Basin: 11-year characterization of atmospheric circulation patterns and dust source areas, Atmos. Chem. Phys., 2014, 14, 6759-75.

7. Blanc, F. De Tomasi, E. Filippo, D. Manno, M. R. Perrone, A. Serra, A. M. Tafuro, and A. Tepore, Characterization of African dust over southern Italy, Atmos. Chem. Phys., 2003, 3, 2147-59.

8. Kevin, D. Perry, Thomas A. Cahill, Robert A. Eldred, and Dabrina D. Dutcher, Longrange transport of North African dust to the eastern United States, Journal of Geophysical Research, 1997, 102, D10, 11225-238.

9. Joseph, M. Prospero, Long-term measurements of the transport of African mineral dust to the southeastern United States: Implications for regional air quality, Journal of Geophysical Research, 1999, 104, DI3, 15, 917-27.

10. Sebastian Engelstaedter, Ina Tegen, Richard Washington, North African dust emissions and transport, Earth-Science Reviews 2006, 79, 73-100.

11. Y. Ben-Ami, I. Koren, and O. Altaratz, Patterns of North African dust transport over the Atlantic: winter vs. summer, based on CALIPSO first year data, Atmos. Chem. Phys., 2009, 9, 7867-75.

12. Dale, W. Griffin, Virginia H. Garrison, Jay R. Herman \& Eugene A. Shinn, African desert dust in the Caribbean atmosphere: Microbiology and public health, Aerobiologia 2001, 17, 203-13.

13. Griffin, D., W., D. L. Westphal, and M. A. Gray, Airborne microorganisms in the African desert dust corridor over the mid-Atlantic ridge, Ocean Drilling Program, Leg 209, Aerobiologia, 2006, 22, 211-26.

14. ESA - TEMIS - http://www.temis.nl/index.php 
15. Dimitrova, M., P. Trenchev, E. Georgieva, N. Neykova, R. Neykova, R. Nedkov, D. Gochev, D. Syrakov, B. Veleva, D. Atanassov, and T. Spassova, Seasonal changes of aerosol pollutants over Bulgaria, Proceedings of the Fifteenth International Scientific Conference Space, Ecology, Safety, SES 2019, (Print ISSN 2603-3313; Online ISSN 2603-3321), 2019, 241-52.

\title{
СЕЗОННО ИЗМЕНЕНИНЕ НА РАЗПРОСТРАНЕНИЕТО НА ПУСТИНЕН ПЯСЬК ОТ САХАРА НАД БАЛКАНИТЕ
}

\author{
М. Димитрова
}

\section{Резюме}

Статията представя едно изследване на сезонното поведение на пустинен пясък от Сахара, който се разпространява над Балканите. Използвани са спътникови данни за месечните стойности на AАI. Данните са от четири инструмента на борда на пет спьтника за периода от юни 1995-та до края на 2019-та. Изследване е правоъгълна област с ьгли съответно 23 Е 43 N and 245 E $35 \mathrm{~N}$. Данните от различните инструменти са сравнени и дискутирани. 